\title{
Chapter 10 \\ Studying Second-Generation Transitions into Adulthood in Switzerland: A Biographical Approach
}

\author{
Eva Mey
}

\subsection{Introduction}

This contribution is based on a biographical study carried out in a little town of Switzerland between 2005 and 2010 (Mey and Rorato 2006, 2010; Mey 2010, 2015). ${ }^{1}$ The study focus on how young men and women from families of migrant background - the so-called second generation-experience and manage the transition from school to professional life and adulthood. The respondents participated in biographical narrative interviews at two points of observation: the first at the end of the compulsory education (i.e., ninth grade), the second three years later.

To capture the specific position (of inequality) of children and adolescents whose parents came to Switzerland as migrant workers from countries of Southern and South-Eastern Europe, our work account for class- and origin-specific inequality dynamics and their interplay. ${ }^{2}$ Following Elias, the relations between migrant workers and the native population can be described as an established-outsider-configuration (Elias and Scotson 1990) in which the "newcomers" find themselves in the social position of outsiders and the natives in the role of the "established" who attempt to maintain their power and privileges. The educational system as a load-bearing social institution is itself part of this constellation and remains unable, despite promises to the contrary, to guarantee equal opportunities for all and eradicate the reproduction

\footnotetext{
${ }^{1}$ The study was financed by the Swiss National Fund and the Swiss Federal Institute of Migration. Between writing this text and its publication, Swiss National Fund has approved the continuation of the research. A third series of interviews with the young adults is planned for 2016.

${ }^{2}$ Theoretically, we draw on Bourdieu (1983) and Elias and Scotson (1990) to conceptualize the intersectionality of class- and figuration-based mechanisms of inequality (see Juhasz and Mey 2003, 2006).

E. Mey $(\bowtie)$

Zurich University of Applied Sciences, Zurich, Switzerland

e-mail: eva.mey@zhaw.ch; https://www.zhaw.ch/de/ueber-uns/person/meyv/
}

C. Bolzman et al. (eds.), Situating Children of Migrants across Borders and

Origins, Life Course Research and Social Policies 7,

DOI 10.1007/978-94-024-1141-6_10 
of social inequalities (Solga 2005; Bourdieu and Passeron 1971). This social constellation is empirically reflected in the migrant workers' weaker position within the educational system and labour market (for Switzerland see Mey et al. 2005; Swiss Education Report 2010; Bergman et al. 2011), and there is persistent origin-driven inequality (Meyer 2009) that is particularly pronounced in Germany and Switzerland compared to the rest of Europe (Hadjar and Berger 2010; Pfeffer 2008). In addition, the Swiss migrants' situation is defined politically and legally by a naturalization regime that, in European standards, is unsurpassed in terms of its strict regulations. It underlines an exclusive concept of Swiss citizenship, which is based on the ideas of origin and identity, and (thus) defines immigrants as basically "others" also in case of second and even third-generation residents.

Our study was carried out in the Swiss municipality of Emmen in the canton of Lucerne. Most of the people in Emmen live in Emmenbrücke, a town with a population of just over 30,000 with a prosperous industrial past and a comparatively high proportion of foreign nationals (about one-third of the population). ${ }^{3}$ The study is hereafter referred to the "EMMEN study". ${ }^{4}$

This article aims to use the EMMEN study to identify the approach, interests, and specific contributions of biographical research in the analysis of the secondgeneration transition into adulthood. The article is structured as follows. In Sect. 10.2 , we give a description of the specific interests and implications of a methodological approach in which biographies - or, more precisely, autobiographical narratives - are both the center and the starting point of the analysis. Section 10.3 focuses on the specific methods applied in the EMMEN study: the sampling, the biographical narrative interviews, and the method of analysis. Particular attention is paid to the fact that the EMMEN study was designed as a biographical longitudinal study. Section 10.4 presents a specific case study to demonstrate the focus of biographical analysis, and its specific findings. The paper concludes with Sect. 10.5 in which some final considerations on the adequacy of the adopted approach are proposed.

\subsection{The Biographical Research Perspective: Interests and Implications}

Our primary interest in biographical research is rooted in a perspective that conceives biographies as "products" of the intersectionality between social conditions and individual action and interpretation. Autobiographical narratives-the "material" of biographical research—reflect the subjective experiences of the individuals,

\footnotetext{
${ }^{3}$ An active community and club life has evolved among some of the immigrant groups that have been living there for some time. In public discourse, Emmen has been given the somewhat derogatory label of a "foreigners' community".

${ }^{4}$ The capitalized EMMEN refers to the town in which the study was carried out as well as to the German subtitle of the study: "Erwachsenwerden Mit Migrationshintergrund: Eine Narrative Studie" (in English: Growing up with a migrant background: A narrative study").
} 
interpretations of these experiences, and the strategies that they develop in their interaction with their environment. Working with autobiographical narratives thus involves another aspect that is crucial for our work. By letting respondents tell their own stories, thereby respecting their personal perspectives and perception of relevance, the biographical approach helps at least to mitigate the problem of "speaking about others"-from which, however, social research can never really escape (e.g., Mecheril 1999).

\subsubsection{Biography and Inequality During Adolescence}

Biographical research offers a sound foundation and excellent conceptual tools for exploring the depths of the intersectionality between social conditions and individual action and interpretation. Worthy of particular mention is Schütze's approach and theoretical toolkit of biographical analysis (1981, 1983, and 2007). ${ }^{5}$ Schütze's analytical method allows the identification of biographical process structures within a biography, which can be distinguished according to whether they are driven by intentional action or by external impulses; "by individual biography incumbents, on the one hand, and the forceful structural restrictions for their activities of production through obligations, constraints and mechanisms of institutional and organizational processes, on the other hand" (Schütze 2007). ${ }^{6}$ As mentioned before, the social conditions in which these biographies unfold can be described and theoretically conceptualized as relations of social inequality in the context of an established-outsider-configuration.

By using Schütze's theoretical biographical approach, it is possible to see individuals neither just as passive victims fully determined by social conditions nor as entirely "free" actors. Such a perspective is particularly important if the research should do justice to the specific quality of adolescence. In her work on adolescence, King (2004) conceptualizes the transition into adulthood as a space of opportunities in which something potentially new unfolds. It is in this space that young people develop — and start to realize - their own biographical models while assessing their previous life experiences, the situation of their families, and social and family norms. Due to the conditions of social inequality and denied recognition, these opportunity spaces are restricted and pre-structured in a specific way. In other words, it is during the transition into adulthood that the relation of inequality and biography becomes particularly a matter of special importance. Previous pathways and social positions are overcome or reproduced during the transition.

\footnotetext{
${ }^{5}$ Schütze is an exponent of "Arbeitsgruppe Bielefelder Soziologen", a group particularly relevant for the advancement of qualitative social research by introducing the Anglo-American debate and important thesis from the respective fields of ethnomethodology, symbolic interactionism and sociology of knowledge to the German-speaking world (Przyborski and Wohlrab-Sahr 2014).

${ }^{6}$ Applying this logic, Schütze identifies four different biographical process structures: biographical action schemes, trajectories of suffering, institutional expectation patterns, and metamorphoses by creative process $(1981,1983$, and 2007). According to Schütze, these fundamental process structures can be found in all biographies, but in changing constellations.
} 
Biographical research targets two outcomes: First, it focuses on analyzing the mechanisms of reproduction as much as on identifying potential for social innovation in adolescent' biography; second, it aims to investigate how these youths perceive the conditions of social inequality, what experiences they have had with it, what strategies they develop to deal with it, what their objectives are in life, and how and in which social contexts these interpretations, strategies, and objectives evolve. By raising such questions, the biographical approach is perfectly suited to track the impact of social inequality and the constraints and restrictions it imposes on the transition into adulthood for second-generation residents down to the level of individual experiences, strategies and sense-making.

\subsubsection{Making Autobiographical Narratives an Object of Investigation}

According to Schütze (1976, 1983), narrative interviews should allow the respondents to tell their stories in their own terms and as freely as possible. This-and only this-produces narratives that allow reconstructing the factual concatenation of life course events and the involvement of the respondent in these concatenations. ${ }^{7}$

Schütze claims that the perceptions and interpretations presented in an autobiographical narrative are always formed by "layers" of previous biographical experience that are "accumulated" over a lifetime. This might be the way by which a young man or young woman of immigrant background tackles a life transition (e.g., from school to work) as well as hopes and fears he or she associates with the process and strategies he or she may employ in dealing with potential obstacles. All of these aspects are shaped not only by previous experiences but also by how the past events were experienced and interpreted at the time. Thus, narratives of a person's life can and must be read and interpreted as a manifestation of all the individual's previous and current efforts of sense-making when he or she seeks to come to terms with the social conditions that constitute the circumstances of his or her life.

By making use of autobiographical narratives, we are therefore able to offer a reconstruction of how concrete experiences have accumulated within a given social context, which in turn allows an understanding of the development of a given biography and of sense-making. Among other things, this particularly sustains efforts to analyze the processes of social (self-)exclusion. Furthermore, by reconstructing the process of sense-making, autobiographical narratives make a person's implicit knowledge accessible. Such implicit knowledge might include the narrator's selfpositioning, comparable to Goffman's sense of one's place (Goffman 1952).

\footnotetext{
${ }^{7}$ This is a central statement of Schütze's narratological approach. His approach involves the thesis of a homology between experienced and narrated history. This thesis has often been criticized and is not shared by all exponents of biographical analysis (for a relevant debates see e.g. Bohnsack 2003 and Przyborski and Wohlrab-Sahr 2014).
} 
Drawing on Schütze, Rosenthal $(1995,2008)$ pays special attention to the dialectic relationship between experience, memory, and narrative. Her methodological conclusion is that "narrated" and "experienced" life history should be analyzed separately, not only in order to consider their dialectic relationship but also to make use of it as a means of analysis. This also makes it possible systematically to include the complex interaction with autobiographical storytelling in the analysis.

Biographical analysis is always based on individual cases. It is not the objective of biographical research to provide information on the quantitative distribution of a specific phenomenon in social reality. Rather, biographical research refers to the logic of reconstructive social research. Underlying the logic of this approach is the assumption that it is possible in principle to identify the general in the particular (Rosenthal 2008:75). The careful biographical reconstruction of each individual case makes it possible to uncover the interplay of relevant factors in all its complexity as well as the nature of the process in each case. The objective is not to use statistical significance to prove the relationship between individual phenomena but to explain these in the context of a single biography. Comparative analysis and the contrasting of single cases (Schütze 1983, based on Glaser and Strauss 1967, Kelle and Kluge 1999) provide a means to spot the variations in the field under study and to describe the various types of biographies in the sense that they represent possible answers to the social problem in question.

\subsection{Design and Methodological Approach in the EMMEN Study}

In the following section, we outline our research design and identify the steps taken to solve the specific challenges involved when collecting and analyzing data. We will address two aspects in more detail: collecting rich data on social networks within a biographical interview and using a longitudinal biographical study design. ${ }^{8}$

\subsubsection{Sample and Survey Design}

The study population consisted of youths aged between 15 and 17 (who ideally had been attending their final year of compulsory education at the time) who were resident in Emmen in the canton of Lucerne, were Swiss or of foreign nationality, and had received their entire schooling in Switzerland. ${ }^{9}$

\footnotetext{
${ }^{8}$ While there are a few studies that apply a qualitative longitudinal design and focus on social networking (e.g., Bidart and Lavenu 2006), we are not aware of any studies that explicitly carry out biographical case reconstructions on the basis of two biographical narratives conducted at different points in time.

${ }^{9}$ The latter criterion was modified in the course of the study. Initially we included students who had been enrolled in Swiss schools for at least 5 years. However, our biographical analyses revealed
} 
To account for the heterogeneity of the field of investigation, the sample was determined by a qualitative sampling scheme in which the national origin, ${ }^{10}$ the level of education attained, ${ }^{11}$ the sex, ${ }^{12}$ as well as the social networking patterns were varied. With regard to social networking, we made sure to include youths involved in formal organizations (some in more than one) as well as youths who only maintain informal networks. In the case of formal organization, we distinguished between those related to the ethnic roots of their members (e.g., Albanian mosque, Serbian dance club, Portuguese school) and those with no such relation (particularly sports clubs). National background was varied so that immigrant groups represented different types of network formation and progression, often depending on the immigration history of the group or the duration of their presence in Switzerland. ${ }^{13}$

The survey design included a first interview, typically made during the final year of compulsory education, and a second interview 3 years later. At the time of the second interview, the young adults were either enrolled in some form of upper secondary education, ${ }^{14}$ had entered gainful employment or were participating in an interim program.

The EMMEN study's sample comprised a total of 34 people of foreign descent who were interviewed twice. ${ }^{15}$

such strong differences in the makeup of the cases involving children who had immigrated during their school years that we decided to no longer consider them to avoid too much heterogeneity (which also suggests that exploring these differences in depth would deserve a study in its own right).

${ }^{10}$ Italy 8, (future) Kosovo 10, Croatia 2, Portugal 8, Serbia 6.

${ }^{11}$ Higher level 5, middle level 12, low level 17 (first point of observation).

${ }^{12}$ Female 15, male 19.

${ }^{13} \mathrm{~A}$ deliberate effort was made to approach the youths through a variety of different channels to minimize potential sample bias. They were approached in public places, via social workers and teachers in schools, through the leadership of sports clubs, at religious institutions (e.g., mosques), or facilities for youths (e.g., youth centers).

${ }^{14}$ This upper secondary education was often a program for vocational education and training (VET), sometimes a more academic education, like high school.

${ }^{15}$ This does not include 8 Swiss youths because their interviews were not systematically included in the analysis. Sample attrition in the time between the first and second interviews (11 persons) was either due to an inability to contact them (7) or refusal to participate (4). The analyses from the first interviews did not allow us to draw any conclusions on a typical profile for the lost cases. For instance, they covered each level of education. 


\subsubsection{Capturing and Interpreting Social Relationships in Biographical Research}

Our study places a particular emphasis on the youths' social relationships, especially, the patterns, changes, and significance of these relationships in the transition from school to adulthood. We were interested in all forms of social networks, including family and kinship as well as peers, both in formal and informal settings (clubs, cliques, best friends, etc.). We claim that they form a social context that not only provides a potential source of social capital (Bourdieu 1983; Portes 1998) but also represents a place where experiences are shared and processed, i.e., that meaning is constructed in processes of social interaction. ${ }^{16}$ Both aspects are particularly relevant in the transition to adulthood. In migration research, there has been a longstanding controversy over the role of ethnic communities for immigrants, i.e., whether (ethnic) community involvement is more likely to open up or restrict opportunities. ${ }^{17}$ Against this background, we sought to identify the various social arrangements in which the youths participated as precisely and exhaustively as possible.

Methodologically, the issue was whether and how this could be achieved within a research design based on autobiographical narratives. The challenge was how to obtain comprehensive information on the respondents' social networks without altering the nature of the biographical interview by too much structured inquiry, thereby contradicting the principle of openness in unstructured interviews. We decided to follow the basic steps of biographical narrative interviewing according to Schütze (1976) (i.e., an unrestrained initial narrative offered by the respondent followed by internal questions, then external questions ${ }^{18}$ ) and addressed social relationships by way of external questions. In so doing, we check carefully that all questions were open questions suited to generating narratives and, whenever possible, to pick up on what had already been said in the interview. ${ }^{19}$ The objective was to find out, for all significant others or groups mentioned, how respondents got to know them or how they came to the group and how the relationship developed and/or ended. In the second round of interviews about 3 years later, we asked the respondents how their contact with all individuals or groups had developed. This procedure frequently pro-

\footnotetext{
${ }^{16} \mathrm{On}$ the significance of peers in the social context of adolescence and migration, see Bohnsack (2003) and Nohl (2001).

${ }^{17}$ See Elwert (1982), Esser (1986), and Portes and Zhou (1993) as some of the most important exponents in the (German- and English-speaking) debate.

${ }^{18}$ Internal questions refer to the narrative, which means they remain within the thematic framework presented by the narrator, whereas external questions reflect the specific thematic interests of the researcher which have not been dealt so far.

${ }^{19}$ Typical questions were, "You spoke of a friend with whom you regularly hung out in high school. Could you tell us how you first met him (or her)?" Or: "At the beginning, you briefly mentioned your brother. Would you mind telling us more about him?" "You mentioned that you had participated in a Catholic youth group some time ago. Could you tell us how it happened that you left the group?"
} 
duced very dense narratives and detailed insights into the youths' networks of social relationships and the changes they had undergone. An important and fruitful consequence of the procedure was that it enabled us to capture the significance of the relationships to the biography as a whole, the development of relations, and the ambivalence involved in some of the youths' social ties (see Sect. 10.4).

\subsubsection{Biographical Research in a Longitudinal Design: Case Reconstructions Spanning Two Points of Observation}

To assess the interviews we applied the method of case reconstruction according to Schütze (1981, 1983, 2007) and Rosenthal (1995, 2008), which we combined in a further step with a case-contrasting method (Schütze 1983, based on Glaser and Strauss 1967, Kelle and Kluge 1999).

A distinctive feature of our study is that we conducted two biographical narrative interviews with a delay of 3 years between them. The interview plan was set up so that the first interview was conducted at the point the subject was completing compulsory education and the second after the beginning of post-compulsory education, thus spanning a specific and critical period in the transition from adolescence into adulthood. As our analyses would later show, this stage of life is not only marked by entering upper secondary education (mostly vocational education and training [VET] in our case) but also by substantial changes in one's social environment upon leaving lower secondary education. The two-time interview design was particularly well suited to analyzing processes and changes that occurred between the first and second interviews. The fact that the interviewees had already told their life history in the first interview, left ample space to talk about the period between the two surveys in the second interview. The quality of the narratives benefited from the respondents being familiar with the interview situation (the second interview was also conducted in the narrative form, preferably by the same person who did the first interview). Moreover, the second interview made it possible to follow up on the topics and storylines of the first interview that had not yet been elaborated.

However, the value of the second interview was not limited to providing extensive data on the period of interest. Besides giving a detailed account of experiences made in the past or in the meantime, it provided a basis for a comparative perspective, allowing contrasting "snapshots" on how the individual saw his or her life, took stock of what had happened so far, and what the person hoped and expected for the future. In some cases, the dominant process structure changed between the first and the second interview, leading to a changed overall interpretation ${ }^{20}$ of all previous experiences.

In practice, the analysis spanning two points in time proved to be quite challenging. We first reconstructed each case based on the first interview. We then turned to

\footnotetext{
${ }^{20}$ Gesamtdeutung, as Schütze puts it in German.
} 
the second interview to reconstruct the subject's life history as it was experienced and narrated (which mostly referred to the period following the first interview). In the next step we compared the first and second interviews in order to identify and interpret relevant changes in biographical process structures and patterns of interpretation and self-presentation. ${ }^{21}$ On this basis, it was possible to integrate the observations made at both points in time into a coherent interpretation.

In a further step, we tried to identify statements that extended beyond the individual cases. The process of analysis mirrored this in that it progressed in various phases, alternating between focusing on a case and an issue. In the first phase, we strictly pursued case analysis according to the procedure described above: all cases were subjected to an initial rough analysis. Selected cases were analyzed in detail. Based on the findings of the first case-centered phase of analysis, we changed the emphasis to cross-case analysis in the next phase. At this point, we focused on comparing the cases to further elaborate and gain a deeper understanding of the issues that were found to be essential to each case. In the process, the relevant issues were always considered in the overall context of the biography, i.e., they were never compared without an understanding of their specific meaning in the case in question (see Sect. 10.4.3).

\subsection{Analyzing Autobiographical Narratives: An Example}

It is beyond the scope of this article to present a complete case reconstruction. The following section is based on excerpts from one specific case-namely, Blerim-to show the topics biographical analysis focuses on and the kind of statements biographical research it can make.

\footnotetext{
${ }^{21}$ In line with Rosenthal, we reconstructed the changes at the level of "experienced" as well as "narrated" life history. Of course, this involved considering the particular situation of a second interview in our biographical analysis and the possible consequences this might have on how things are presented or narrated. For instance, some respondents carefully referred as precisely as possible to what had been said during the first interview, which gave to the narrative a different structure from the case in which a respondent who hardly remembered the first interview. But a biographical narrative must always also be treated as the product of a specific interview situation. In this respect, there is essentially no difference between our analysis of the first and second interviews. In our view, Rosenthal's methodology with its separate analyses of "narrated" and "experienced" life history offers an excellent framework for dealing with the methodological consequences not only in the case of a one-time interview but also in the case of a longitudinal biographical study.
} 


\subsubsection{Blerim's Biography}

Blerim $^{22}$ is the oldest son of a family of five. He has been living in Emmenbrücke since his childhood. The family has to move regularly as it is difficult to find an apartment that is both big enough to accommodate the entire family and that the family can afford on a small budget. Blerim's father came to Switzerland many years ago to look for work. The mother and the children followed later. The family has many close relatives living in the same area and in other parts of Switzerland with whom they have close contact. Blerim's father is a qualified imam but in Switzerland he works in construction. Blerim's mother is a qualified baker and works in the food sector. At the time of the first interview, Blerim had just finished compulsory education. The second interview took place when he was in the middle of post-compulsory vocational education (VET).

Giving the story of his parents' (that is, his father's) immigration at an early stage during the first interview, Blerim says: "Because of work. He came to earn money. And then, like every foreigner, he brought his family over. Because they took ... they found ... they got a place here."

These words contain more than basic information on his family's migration; Blerim's search for the right word (took, found, got a place) additionally reflects his difficulty in interpreting and defining his family's status in the host country. Blerim's interpretation oscillates between various poles, active and passive, between taking and being offered a place (by the locals), between taking and not taking his family's life in Switzerland for granted. The two poles represent two possible ways that the son of a migrant working family in Switzerland might make sense on the immigrant experience. ${ }^{23}$ At this point, we can already suspect this interpretation to indicate an area of tension that surfaces repeatedly in the course of the first interview with Blerim and plays a key role in his biography. Blerim switches back and forth between both lines of interpretation and the associated biographical attitudes and projects.

\subsubsection{Processes of Exclusion and Self-Exclusion}

Blerim's narrations during the first interview indicate that the processes of exclusion and self-exclusion kick in at an early age. He remembers an occurrence from his early school days: In first grade he and two other children used to go to special German lessons and therefore had to leave the classroom regularly. Blerim tells how the three of them, on leaving the classroom, would form a line and howl loudly because they saw themselves as a little "gang." The teacher managed to stop these

\footnotetext{
${ }^{22}$ The name is a pseudonym; additionally some personal information has been anonymized.

${ }^{23}$ The variant he ultimately opts for in this interview situation is certainly not coincidental but is rather an interpretation that he believes to better correspond to the definition of the interviewer (as a member of "the establishment").
} 
early attempts at self-exclusion with which the children sought to cope with their separation from the class; he says she suggested that the whole class form a gang: "We were then the gang of [room] 1A," he recalls. Two things are clear from this narrated episode: first, how symbolic equality can be experienced in belonging to a group in elementary school as a school for all; and second, that this episode and its temporary happy ending were so important to Blerim and his biographical construction that he remembers and talks about them. Both aspects are of interest in biographical research and are reconstructed by it. This act of reconstruction takes into account the experience as such (and its impact on consequences for the biography) as well as the ways it is recalled.

During his early childhood years, Blerim liked going to school and describes himself as a bright pupil. But outside of school the processes of exclusion and selfexclusion continued their course. Blerim tells how he tried to affiliate in various clubs, among them the Boy Scouts, but he soon left. The others "didn't like" him, as he puts it.

\subsubsection{Critical Years - Diminishing Opportunities and Loss of Agency}

When Blerim was about 12 years old, a number of things happened that were beyond his control and had a profound effect on him. His father became sick, a planned return to Kosovo was cancelled, and the family had to move again. In his new neighbourhood and school, Blerim came to know new and "wrong friends," as he puts it in the first interview. He joined a gang of foreign youths that scrapped with a right-wing extremist gang (thus differentiations along national and ethnic lines became dominant), took up smoking, started neglecting schoolwork, and no longer earned the same high grades as he once did. He began trying out informal, confrontational strategies (Keller et al. 2012). In this new environment, he experienced a sense of belonging, whereas he increasingly lost the resources to actively shape his own life.

His next set of experiences can be outlined as follows: Blerim's father managed to get his son to distance himself from his friends by looking for him whenever they were out together and bringing him back home time and again. Blerim expresses his gratitude ("he was always interested in me"); yet at the same time, this experience affirmed his lack of autonomy. However, at school it soon became clear that this short confrontational period would have a lasting effect on Blerim's biography. His efforts to make up the backlog of schoolwork and to put his educational career back on track (as might have been possible coming from a more privileged family with recourse to extra classes or a private school) failed. Blerim left school as a young man with an Albanian name and a Realschul-level graduation certificate (Realschule is the bottom tier of upper secondary education in the Swiss educational system). He did not gain access to VET. The end of compulsory schooling thus left its mark on Blerim's life. He was no longer a part of any institutional network. Furthermore, he lost touch with his former classmates, something which he greatly regrets at the time of his first interview. Most of the time he stays at home. He is alone and does not work. "I would like to build a good future. But we will have to see what hap- 
pens," is Blerim's closing statement in the first interview. He is close to losing his belief in his own capacity for action.

\subsubsection{Resources from Within the Community}

In this critical period of his life, it was ultimately his family and community network that provided Blerim with support. He started making Albanian rap with two cousins and a friend of theirs. With a commitment that expressed their sincere desire to manage and shape their own lives, the young men set up a small music studio. Blerim started writing lyrics for himself and others. It was here that he was once again able to experience a sense of self-efficacy. After a few months, Blerim's mother-using what little social capital she had-found her son a job as an unskilled laborer in the company where she worked. Blerim's joy and the relief he felt over having a job ("like everyone else") is reflected in a long narrative on his first day at work. He was committed to his work and was appreciated for it, but he knew that he could not build a secure future without any professional training. Strengthened by his experiences with self-efficacy and recognition for his music activities and at work, he kept searching for access to the VET system. He was supported by his line manager, who gave him good references. Finally — after having worked more than a year and a half in the first labour market-Blerim found a way into the VET as a floor layer. In his second interview, he talks a lot about his work activities, expressing his occupational identification with his new workplace. Blerim is already thinking about enrolling in continuing education.

\subsubsection{Increasing Autonomy}

"I mean, I can lay a floor," says Blerim in the second interview. Although this sentence refers to his vocation as a floor layer, it can also apply to Blerim's life in general in light of the increasing opportunity space and autonomy he has found and experienced. In addition to his vocation, Blerim has become increasingly successful with his music. He is well known in the broader Kosovo-Albanian youth culture beyond the canton of Lucerne. And when an Albanian television station recently aired a short report on his music studio via satellite "to the whole world" (Blerim), this attention even took on a transnational dimension. We should mention here that Blerim has successfully used his exposure to youth culture to emancipate himself from his parents, to whom he remains close. His parents seriously dislike their son's music (and the corresponding milieu). Blerim, with his self-confidence bolstered by his success, but also in sympathy with his father, says: "It is not easy when an imam becomes a rapper" (referring to his background as the son of an imam).

By the time of the second interview, Blerim has managed to establish a foundation for leading a secure and autonomous adult life. He likes living in Emmen, and he defines and presents himself as a floor layer planning to continue education and as a young musician. However-and all the more important against the background 
and presentation just outlined - an important subject for him continues to be denied social recognition. In his narrative, he refers to the difficulties of obtaining Swiss citizenship and to xenophobic public and media discourse, including the debate on what had been coined "foreign speed maniacs". This debate was raging at that time and focused particularly on young (Kosovo-) Albanians who were stigmatized as irresponsible drivers, and Blerim reveals how much this negative discourse has hurt him emotionally. At the time of the second interview, Blerim had not yet decided if he would ever apply for Swiss citizenship. In this respect, he still feels uncertain about his status and place in Swiss society.

\subsubsection{Summary}

Blerim's biography illustrates the fragility of adolescence in an established-outsiderconfiguration (Elias and Scotson 1990, see Sect. 10.1). His narrative reveals the processes of exclusion and self-exclusion that led him to test confrontational strategies for a brief period at an early stage in his life, while the dynamics and mechanisms involved therein had driven him on the verge of precarity upon completing secondary school. After leaving the path of confrontation, however, the limited opportunities and resources available in his social situation prevented him from simply returning to the path of conformity that he once pursued. It is primarily through family-internal and ethnic resources that it became possible for him to stabilize his situation (e.g., with his father's and mother's support, or spaces in which to experience self-efficacy). We can see how and based on which experiences Blerim regained confidence in his own agency and how he managed to finally gain access to vocational training, thus introducing the prospect of having a career at the time of the second interview. He has established a solid foundation for occupational stability in the future. His commitment to and success within Kosovo-Albanian youth culture has facilitated his emancipation from his parents while he has availed himself of its transnational spaces, which can indeed be seen as an "innovative" defining feature of his adolescence (see King, Sect. 10.2.1). Despite these successful steps toward adulthood, his desire for recognition as a fully valued member of Swiss society nevertheless remains unfulfilled, which can be seen as a biographical disposition that harbors persistent potential for emotional pain throughout his life and a situation that keeps him away from legal equality by attaining Swiss citizenship.

\subsubsection{Cross-Case Analysis Beyond Blerim}

We want to show here, briefly, how we compared cases to identify statements extending beyond the individual case (see Sect. 10.3.3). We again base this on the example of Blerim. Our comparisons refer to the specific biographical process structures (see Sect. 10.2.1) observed for Blerim (e.g., early period of active 
confrontational strategies followed by an increasing loss of agency, increasing autonomy later on). Blerim's case was compared to other cases with a similar biographical structure to further investigate the corresponding biographical constellations (orientation pattern, family and peer situation) in which such a crisis develops. Furthermore, we compared cases where the crisis could be "reversed," as with Blerim, and cases where this was no longer possible. In so doing, we identified the specific personal strategies and resources that could be used to achieve the turnaround or which were unavailable.

On this basis it was also possible to carry out topic-focused case comparisons. For example, we used the specific role of the community as the point of departure for Blerim. In comparing his with other cases, it was possible to investigate whetherand in which constellations - the community plays a supplementary role with regard to the occupational sphere (opportunities to experience self-efficacy and recognition in the occupational sphere as well as in the community), or a compensatory role (community as the only space to find at least some resources and opportunities to develop and realize own ideas and projects). The case comparisons also allowed identifying gender-specific features. For example, in contrast to Blerim, the search for recognition and self-efficacy within the community for a young woman of Kosovar background did not lead to commitment to and success as a musician but rather to plans for starting her own family at an early age. This approach was supported by the fact that our study sample was comparatively large for a biographical (reconstructive) research project and it included variation along important dimensions, such as gender, level of education, and patterns of social relationships. This enabled us to develop systematic and fruitful case comparisons in order to answer the research questions that cropped up repeatedly (e.g., the role of the community).

\subsection{Conclusion}

Making statistically corroborated statements about the reality of the lives of secondgeneration residents is not the objective of biographical research; such statements necessarily escape the focus and scrutiny of biographical research. However, biographical research can use individual cases to reconstruct and show the specific logic in which biographies develop in a specific social context. The careful reconstruction of individual biographies, as well as theoretically driven contrasting of cases, makes it possible to identify not only the specific resources but also the critical moments and vulnerability dispositions in people's lives.

It was not the aim of this methodological discussion to present a comprehensive account of the findings in our EMMEN study (See Mey and Rorato 2006, 2010; Mey 2010, 2015). The example of Blerim discussed here is meant to provide insight into our work with biographies - or more precisely, with autobiographical narratives. Both shape a biography and should be included in the analysis: the experiences of an individual in his or her specific social context and the manner in which he or she interprets, remembers, and talks about these experiences. 
The advantage of having access to biographical narratives at two points in time became clear as it allows for a comparative analysis of the changes or continuity in the biographical structure and the dominant patterns of interpretation. Our specific focus on the young people's social networks in the biographical interviews turned out to be another advantage, as it provided us with a rich source of diverse information about the genesis and the relevance of social networks in the transition into adulthood. And the relatively large sample for our case-reconstructive project has proved to be an excellent base for further differentiation of our findings and to identify statements extending beyond the individual case.

On a final note I would like to point out that working with biographical material always encourages us to question the ideas and standards used by the public - and often also by researchers - to assess biographies and in particular the transition into adulthood. What seems to the outside world to be an easy transition into the workplace because it happens quickly and "quietly" does not always prove to be the transition that is subjectively experienced as the one that is most satisfactory to a given individual and that meets his or her requirements for an independent life. And the opposite is also true. Those biographies and transitions that seem to be very difficult and plagued by personal crisis can provide a great deal of subjective satisfaction and hold potential for social innovation.

Acknowledgments This paper benefited from the support of the Swiss National Centre of Competence in Research LIVES-Overcoming Vulnerability: Life Course Perspectives, which is financed by the Swiss National Science Foundation (Grant number: 51NF40-160590).

\section{References}

Bergman, M., Hupka-Brunner, S., Keller, A., Meyer, T. und Stalder, B. E. (2011). Transitions juvéniles en Suisse: Résultats de l'étude longitudinale TREE. Zurich: Seismo.

Bidart, C., \& Lavenu, D. (2006). Transitions vers la vie adulte et origines sociales: une enquête longitudinale en France. In C. Bidart (Ed.), Devenir adulte aujourd'hui: perspectives internationales (pp. 163-180). Paris: L'Harmattan-INJEP (Débats-Jeunesse). http://halshs.archivesouvertes.fr/halshs-00133025/PDF/devenir_adulteCHAPX.pdf . Accessed 13 August 2015.

Bohnsack, R. (2003). Rekonstruktive Sozialforschung. 5. Auflage. Opladen: Leske und Budrich.

Bourdieu, P. (1983). Ökonomisches Kapital, kulturelles Kapital, soziales Kapital. In R. Kreckel (Ed.), Soziale Ungleichheiten (pp. 183-198). Gottingen: Schwartz.

Bourdieu, P., \& Passeron, J.-C. (1971). Die Illusion der Chancengleichheit. Untersuchungen zur Soziologie des Bildungswesens am Beispiel Frankreichs. Stuttgart: Klett.

Elias, N., \& Scotson, J. L. (1990). Etablierte und Aussenseiter. Zur Theorie von EtabliertenAussenseiter-Beziehungen. Frankfurt am Main: Suhrkamp.

Elwert, G. (1982). Probleme der Ausländerintegration. Gesellschaftliche Integration durch Binnenintegration? Kölner Zeitschrift für Soziologie und Sozialpsychologie, 34, 717-731.

Esser, H. (1986). Ethnische Kolonien: ‘Binnenintegration' oder gesellschaftliche Isolation? In J. H. P. Hoffmann-Zlotnik (Ed.), Segregation oder Integration. Die Situation von Arbeitsmigranten im Aufnahmeland (pp. 106-117). Mannheim: Forschung, Raum und Gesellschaft.

Glaser, B. G., \& Strauss, A. L. (1967). The discovery of the grounded theory. Chicago: Aldine.

Goffman, E. (1952). On cooling the mark out. Some aspects of adaption to failure. Psychiatry, 15(4), 451-467. 
Hadjar, A., \& Berger, J. (2010). Dauerhafte Bildungsungleichheiten in Westdeutschland, Ostdeutschland und der Schweiz: Eine Kohortenbetrachtung der Ungleichheitsdimension soziale Herkunft und Geschlecht. Zeitschrift für Soziologie, 39, 182-201.

Juhasz, A., \& Mey, E. (2003). Die zweite Generation: Etablierte oder Aussenseiter? Biographien von Jugendlichen ausländischer Herkunft. Wiesbaden: Westdeutscher Verlag.

Juhasz, A., \& Mey, E. (2006). Adoleszenz zwischen sozialem Aufstieg und sozialem Ausschluss. In V. King \& H.-C. Koller (Eds.), Adoleszenz - Migration - Bildung. Bildungsprozesse Jugendlicher und junger Erwachsener mit Migrationshintergrund (pp. 85-102). Wiesbaden: VS Verlag für Sozialwissenschaften.

Kelle, U., \& Kluge, S. (1999). Vom Einzelfall zum Typus. Fallvergleich und Fallkontrastierung in der qualitativen Sozialforschung. Opladen: Leske + Budrich.

Keller, C., Tucci, I., Jossin, A., und Groh-Samberg, O. (2012). Prekäre Verläufe von Jugendlichen mit Migrationshintergrund in Deutschland und Frankreich. In J. Mansel, \& K. Speck (Eds.), Jugend und Arbeit. Eine Bestandesaufnahme und Analysen (pp. 135-156). Weinheim und Basel: Beltz Juventa.

King, V. (2004). Die Entstehung des Neuen in der Adoleszenz. In Individuation, Generativität und Geschlecht in modernisierten Gesellschaften. Wiesbaden: VS Verlag für Sozialwissenschaften.

Mecheril, P. (1999). Wer spricht und über wen? Überlegungen zu einem (re-) konstruktiven Umgang mit dem Anderen des Anderen in den Sozialwissenschaften. In W. Bukow \& M. Ottersbach (Eds.), Die Fundamentalismusdebatte (pp. 231-266). Opladen: Leske + Budrich.

Mey, E. (2010). Blockierte Secondas und Secondos. Biographische Studien zur Integration von Jugendlichen mit Migrationshintergrund. Widerspruch, 59, 45-54.

Mey, E. (2015). Wege in die Arbeitswelt - dorthin, wo noch Platz ist. Mechanismen und Bedeutung stark fremdbestimmter Berufswahl bei jungen Menschen mit Migrationshintergrund. In T. Geisen, M. Ottersbach (Hrsg.) Arbeit, Migration und Soziale Arbeit. Prozesse der Marginalisierung in modernen Arbeitsgesellschaften (pp. S.235-S.262). Wiesbaden: Springer VS.

Mey, E. \& Rorato, M. (2006). Soziale Vernetzung von Jugendlichen mit Migrationshintergrund. Eine qualitativ-empirische Studie in der Gemeinde Emmen. Schlussbericht zuhanden der Eidgenössischen Ausländerkommission. Luzern.

Mey, E. \& Rorato, M. (2010). Jugendliche mit Migrationshintergrund im Übergang ins Erwachsenenalter - eine biographische Längsschnittstudie. Schlussbericht. http://www.hslu. ch/emmen. Accessed 13 Aug 2015.

Mey, E., Rorato, M., \& Voll, P. (2005). Die soziale Stellung der zweiten Generation. Analysen zur schulischen und beruflichen Integration der zweiten Ausländergeneration. In Eidgenössische Volkszählung 2000 (pp. 61-152). Neuchâtel: Bundesamt für Statistik.

Meyer, T. (2009). Wer hat, dem wird gegeben. Bildungsungleichheit in der Schweiz. In C. Suter, S. Perrenoud, R. Levy, U. Kuhn, D. Joye, \& P. Gazareth (Eds.), Sozialbericht 2008 (pp. 60-81). Zürich: Seismo.

Nohl, A.-M. (2001). Migration und Differenzerfahrung. Junge Einheimische und Migranten im rekonstruktiven Milieuvergleich. Opladen: Leske + Budrich.

Pfeffer, F. (2008). Persistent inequality in educational attainment and its institutional context. European Sociological Review, 24(5), 543-565.

Portes, A. (1998). Social capital: Its origins and applications in modern sociology. Annual Review of Sociology, 24, 1-24.

Portes, A., \& Zhou, M. (1993). The new second generation: Segmented assimilation and its variants. The Annals of the American Academy of Political and Social Science, 530, 74-96.

Przyborski, A., \& Wohlrab-Sahr, M. (2014). Qualitative Sozialforschung. 4., erweiterte Auflage. München: Oldenburg Verlag.

Rosenthal, G. (1995). Erlebte und erzählte Lebensgeschichte. Gestalt und Struktur biographischen Selbstbeschreibungen. Frankfurt/Main: Campus Verlag.

Rosenthal, G. (2008). Interpretative Sozialforschung. Eine Einführung. Weinheim und München: Juventa. 
Schütze, F. (1976). Zur Hervorlockung und Analyse von Erzählungen thematisch relevanter Geschichten im Rahmen soziologischer Feldforschung. In A. B. Soziologen (Ed.), Kommunikative Sozialforschung (pp. 159-260). München: Wilhelm Fink.

Schütze, F. (1981). Prozessstrukturen des Lebensablaufes. In J. Matthes, A. Pfeifenberger, \& M. Stosberg (Eds.), Biographie in handlungswissenschaftlicher Perspektive (pp. 67-156). Nürnberg: Sozialwissenschaftliches Forschungszentrum des Universität Erlangen-Nürnberg.

Schütze, F. (1983). Biographieforschung und narratives Interview. Neue Praxis, 3, 283-294.

Schütze, F. (2007). Biography analysis on the empirical base of the autobiographical narratives: How to analyze autobiographical narrative interviews. Part 1 und 2. INVITE - Biographical Counseling in Rehabilitative Vocational Training. Further Education Curriculum. EU Leonardo da Vinci Programme. www.biographicalcounselling.com/download/B2.1.pdf. Accessed 13 Aug 2015.

SKBF Swiss Coordination Centre for Research in Education. (2010). Swiss education report 2010. Aarau: SKBF.

Solga, H. (2005). Meritokratie - die moderne Legitimation ungleicher Bildungschancen. In P. A. Berger \& H. Kahlert (Eds.), Institutionalisierte Ungleichheiten? (pp. 19-38). Weinheim: Juventa.

Open Access This chapter is licensed under the terms of the Creative Commons Attribution 4.0 International License (http://creativecommons.org/licenses/by/4.0/), which permits use, sharing, adaptation, distribution and reproduction in any medium or format, as long as you give appropriate credit to the original author(s) and the source, provide a link to the Creative Commons license and indicate if changes were made.

The images or other third party material in this chapter are included in the chapter's Creative Commons license, unless indicated otherwise in a credit line to the material. If material is not included in the chapter's Creative Commons license and your intended use is not permitted by statutory regulation or exceeds the permitted use, you will need to obtain permission directly from the copyright holder.

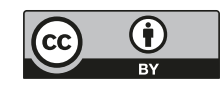

